\title{
Optimization of ultraviolet ozone treatment process for improvement of polycaprolactone (PCL) microcarrier performance
}

\author{
Nurhusna Samsudin • Yumi Zuhanis Has-Yun Hashim • Mohd Azmir Arifin • \\ Maizirwan Mel · Hamzah Mohd. Salleh · Iis Sopyan · Dzun Noraini Jimat
}

Received: 12 October 2016/Accepted: 24 January 2017/Published online: 23 March 2017

(C) Springer Science+Business Media Dordrecht 2017

\begin{abstract}
Growing cells on microcarriers may have overcome the limitation of conventional cell culture system. However, the surface functionality of certain polymeric microcarriers for effective cell attachment and growth remains a challenge. Polycaprolactone (PCL), a biodegradable polymer has received considerable attention due to its good mechanical properties and degradation rate. The drawback is the non-polar hydrocarbon moiety which makes it not readily suitable for cell attachment. This report concerns the modification of PCL microcarrier surface (introduction of functional oxygen groups) using ultraviolet irradiation and ozone $\left(\mathrm{UV} / \mathrm{O}_{3}\right)$ system and investigation of the effects of ozone concentration, the amount of PCL and exposure time; where the optimum conditions were found to be at 60,110.52 ppm, $5.5 \mathrm{~g}$ PCL and $60 \mathrm{~min}$, respectively. The optimum concentration of carboxyl group $(\mathrm{COOH})$
\end{abstract}

N. Samsudin · Y. Z. H.-Y. Hashim ( () .

M. A. Arifin · M. Mel · H. Mohd. Salleh $(\varangle)$.

D. N. Jimat

Department of Biotechnology Engineering, Kulliyyah of Engineering, International Islamic University Malaysia, P.O. Box 10, 50728 Kuala Lumpur, Malaysia

e-mail: yumi@iium.edu.my

H. Mohd. Salleh

e-mail: hamzah@iium.edu.my

Y. Z. H.-Y. Hashim · H. Mohd. Salleh

International Institute for Halal Research and Training (INHART), International Islamic University Malaysia, Level 3, KICT Building, P.O. Box 10,

50728 Kuala Lumpur, Malaysia absorbed on the surface was $1495.92 \mathrm{nmol} / \mathrm{g}$ and the amount of gelatin immobilized was $320 \pm 0.9 \mu \mathrm{g} / \mathrm{g}$ on $\mathrm{UV} / \mathrm{O}_{3}$ treated microcarriers as compared to the untreated $(26.83 \pm 3 \mu \mathrm{g} / \mathrm{g})$ microcarriers. The absorption of functional oxygen groups on the surface and the immobilized gelatin was confirmed with the attenuated total reflectance Fourier transformed infrared spectroscopy (ATR-FTIR) and the enhancement of hydrophilicity of the surface was confirmed using water contact angle measurement which decreased $\left(86.93^{\circ}-\right.$ $49.34^{\circ}$ ) after $\mathrm{UV} / \mathrm{O}_{3}$ treatment and subsequently after immobilization of gelatin. The attachment and growth kinetics for HaCaT skin keratinocyte cells showed that adhesion occurred much more rapidly for oxidized surfaces and gelatin immobilized surface as compared to untreated PCL.

\footnotetext{
M. A. Arifin

Faculty of Engineering Technology, Universiti Malaysia Pahang, Lebuhraya Tun Razak, 26300 Gambang, Kuantan, Pahang, Malaysia

I. Sopyan

Department of Manufacturing and Material Engineering, Kulliyyah of Engineering, International Islamic University Malaysia, P.O. Box 10, 50728 Kuala Lumpur, Malaysia
} 
Keywords Microcarrier - Polycaprolactone (PCL) . Ultra violet ozone $\left(\mathrm{UV} / \mathrm{O}_{3}\right) \cdot$ Gelatin immobilization . Surface modification

\section{Introduction}

Microcarrier cell culture system served two significant purposes. First, it is to mass produce large amounts of certain bioproducts such as recombinant proteins, hormones, and vaccines, where animal cells are routinely cultured in a bioreactor to meet industrial demand (van der Velden-de Groot 1995) and clinical trial stage (Goh et al. 2013). The second purpose is to serve as delivery of cultured cells (Seland et al. 2011). Therefore, materials with appropriate degradation rate are favorable in microcarrier cell culture system to reduce the effect of toxic degradation products. Polycaprolactone (PCL), a semi-crystalline polymer, undergoes a two-stage degradation process, the nonenzymatic hydrolytic cleavage of ester group (amorphous area) followed by the second stage of intracellular degradation (Chen et al. 2000). In a work on smooth muscle cells cultured on PCL microcarrier, the initial degradation products and chemical leaching from the polymer were found to be non-toxic to cells (Steynberg et al. 2012). This suggests that the slow degradation rate of PCL causes only relatively small local $\mathrm{pH}$ changes thus does not exert unfavorable effects on the cells.

Bulk chemistry, surface charge, wettability and hydrophilicity of the microcarrier surface have been reported to be the primary factors in determining cell behavior for in vitro cultures (Mano et al. 2007). Cells will grow on the outer surface of a microcarrier until they form a confluent monolayer. Each microcarrier can accommodate 100-200 cells. The density of a microcarrier is approximately $1.02-1.04 \mathrm{~g} / \mathrm{cm}^{3}$, which is slightly higher than that of the culture medium (GE Healthcare handbook 2005). The ideal size for a microcarrier is in the $100-500 \mu \mathrm{m}$ range and narrow size distribution is important to ensure size uniformity and easy maintenance in suspension at low agitation speeds (Bock et al. 2009; Zhou et al. 2013).

Several surface modification techniques have been developed to improve wetting, adhesion, and compatibility of polymer surfaces to cells (Ratner et al. Ratner and Bryant 2004). Surface modification methods, such as plasma treatment, gamma irradiation, ozone- or photo-induced grafting, ultraviolet/ozone $\left(\mathrm{UV} / \mathrm{O}_{3}\right)$ and chemical surface oxidation, have been employed to introduce functional groups on surfaces with minimal alteration of bulk properties, resulting in improved cell attachment, spreading, and proliferation (Yang et al. 2003; Ma et al. 2002; Shen et al. 2007; Yusilawati et al. 2010). Among these techniques, UV/ $\mathrm{O}_{3}$ and plasma treatment are widely used.

$\mathrm{UV} / \mathrm{O}_{3}$ has been shown to be a highly successful method for controlled modification of polymer and or production of surfaces for enhanced cell attachment (Teare et al. 2000, 2001; Mitchell et al. 2004). UV/O 3 treatment has many advantages over other methods for surface modification of polymer because it is cost effective and involves only simple apparatus with no requirement of vacuum systems. $\mathrm{UV} / \mathrm{O}_{3}$ treatment can also give precise control over the modification process even with the absence of any wet chemistry. Ozonation treatment with UV light can easily be carried out in various gasses, solvents and solutions at room temperature and this method is suitable for heatunstable materials such as organic substrates (Clark et al. 2000; Davidson et al. 2004).

Recently, it became of interest to immobilize proteins or oligopeptides onto polymer surface as it significantly improves the biocompatibility of the polymer (Ma et al. 2002). Immobilization of biologically active molecules can generate a specific, predictable and controlled response from the cells seeded on the materials (Yuan et al. 2012). Several mechanisms can be employed in protein immobilization, such as physical or chemical adsorption, physical encapsulation and chemical combination (Kwon et al. 2006; Khan et al. 2007). Carbodiimide coupling reagents are the most popular type of zero-length crosslinker in the immobilization process. Watersoluble carbodiimides are the most common choice for biochemical conjugations because most macromolecules of biological origins are soluble in aqueous buffer solutions. Not only the carbodiimide itself is able to dissolve in the reaction medium, but the byproduct of the reaction, an isourea, is also watersoluble, facilitating easy purification. Among the carbodiimide; EDAC (1-ethyl-3-(3-dimethylaminopropyl) carbodiimide hydrochloride) and EDAC/ NHS (1-ethyl-3-(3-dimethylaminopropyl) carbodiimide hydrochloride/ $N$-hydroxysuccinimide) are frequently used to immobilize biomolecules such as 
gelatin on functionalized carrier (Zhu et al. 2002; Khan et al. 2007). EDAC/NHS-coupled reactions are highly efficient and can usually, increase the yield of conjugation than EDAC alone. Khan et al. (2007) claimed that EDAC/NHS strategy provides a good platform to improve the biocompatibility for various biomedical purposes.

In the present study, the surface polarity of PCL was modified using ultraviolet ozone $\left(\mathrm{UV} / \mathrm{O}_{3}\right)$ system with the goal to afford microcarriers that readily provide appropriate surface for gelatin immobilization with the introduction of surface hydroxyl, carbonyl, and carboxylic acid groups. The $\mathrm{UV} / \mathrm{O}_{3}$ system involved a simple apparatus with no vacuum systems or sophisticated gas handling. The surface modification process was statistically optimized in order to achieve optimum gelatin immobilization, thus improved cell attachment on the microcarrier. Topographical and chemical changes induced upon optimization of PCL microcarrier surfaces were characterized using scanning electron microscopy (SEM), attenuated total reflectance Fourier transform infrared spectroscopy (ATR-FTIR) and contact angle. Gelatin was then immobilized on the optimized surface-modified PCL microcarrier. Human keratinocytes $(\mathrm{HaCaT})$ cell growth and expansion on the untreated, $\mathrm{UV} / \mathrm{O}_{3}$ treated and $\mathrm{UV} / \mathrm{O}_{3}$-gelatin coated PCL microcarriers were observed and compared.

\section{Materials and methods}

Materials, chemicals and reagents

Pellet polycaprolactone (PCL) $(\mathrm{Mn}=45,000)$, dichloromethane (DCM), polyvinyl alcohol (PVA), sodium hydroxide and hydrochloric acid were supplied by Sigma-Aldrich (St. Louis, MO, USA). $\mathrm{N}$ hydroxysuccinimide (NHS), sodium bicarbonate and sodium dodecyl sulfate (SDS) were purchased from Merck Millipore (Darmstadt, Germany). Toluidine Blue O (TBO) was supplied by Bendosen Laboratory Chemical (Selangor, Malaysia). 2-( $N$-morpholino) ethane sulfonic acid (MES), $\mathrm{Ca}^{2+}$ and $\mathrm{Mg}^{2+}$-phosphate buffer (PBS) and 1-ethyl-3-(3-dimethylaminopropyl)-carbodiimide (EDAC) were purchased from EMD Chemical Inc. (Cincinnati, OH, USA). Pure oxygen gas (99\%) was supplied by Linde Malaysia Sdn. Bhd (Selangor, Malaysia) and Total Collagen Assay Kit was purchased from QuickZyme Bioscience (Leiden, Netherlands). Dulbecco's modification of Eagle's medium (DMEM) in powder form, fetal bovine serum (FBS) and antibiotics (100 U/ml penicillin, $0.1 \mathrm{~g} / \mathrm{l}$ streptomycin) were supplied by Gibco (Grand Island, NY, USA). Accutase was obtained from Innovative Cell Technologies (San Diego, CA, USA) whereas bovine gelatin was purchased from Halagel (Kedah, Malaysia).

Cell line

A spontaneous immortalized continuous HaCaT (skin keratinocytes of adult human) was used throughout the study. The cell line was purchased from Cell Lines Service (CLS, Eppelheim, Germany) Cat. No. 300493. Cells were kept cryopreserved in liquid nitrogen until further use.

Preparation of PCL microcarriers

Polycaprolactone (PCL) microcarriers were prepared according to emulsion solvent evaporation process as described by Maia and Santana (2004) with several modifications. PCL (10 g) were dissolved in dichloromethane $(90 \mathrm{ml})$ and the mixture was stirred on a hot plate magnetic stirrer (Ika C mag HS7, Staufen, Germany) to obtain a homogeneous solution. The dissolved mixture was then added dropwise into a polyvinyl alcohol (PVA) solution which acts as a surfactant. The resulting emulsion was stirred using an overhead stirrer (Ika RW 20 digital) at $250 \mathrm{rpm}$ for $6 \mathrm{~h}$ at $25{ }^{\circ} \mathrm{C}$. The microcarriers were collected by vacuum filtration (Sartorius Stedim, Göttingen, Germany) and were washed with distilled water and dried in $30{ }^{\circ} \mathrm{C}$ oven for $12 \mathrm{~h}$. The particles were then stored in vacuum at $5{ }^{\circ} \mathrm{C}$ until ready to use.

Preparation of PCL film

Polycaprolactone (PCL) film was prepared by a solution casting method by dissolving PCL in dichloromethane (9wt\%). The dissolved PCL was placed in a glass Petri dish. The solvent was allowed to evaporate at $25^{\circ} \mathrm{C}$. The film was then removed from the Petri dish after overnight drying at $25^{\circ} \mathrm{C}$. 
$\mathrm{UV} / \mathrm{O}_{3}$ treatment process

The prototype system used for oxidization of microcarriers' surface was set following Murakami et al. (2005). The system was equipped with an ozone generator (Absolute ozone Nano, Edmonton, Alberta, Canada) that can supply 5-10\% (w/w) ozone with oxygen $\left(\mathrm{O}_{2}\right)$ flow rate of $0.1-4 \mathrm{lpm}$. Pure supply of oxygen gas was controlled by a flow rate meter with maximum flow rate of $5 \mathrm{lpm}$ at a constant standard working pressure of 20 psig. The $\mathrm{O}_{2}$ gas was channeled to an $\mathrm{O}_{2}$ inlet port lined with polytetrafluoroethylene (PTFE) gas tubing. Ozone was generated as the $\mathrm{O}_{2}$ gas flows through an electrical discharge and channeled out through the outlet port to the Dresher bottle placed in a self-fabricated UV box. UV-C germicidal lamps (Sanyo Denki, Tokyo, Japan) were mounted in the UV box. The lamps emit radiant energy of $253.7 \mathrm{~nm}$ wavelength and a controlled amount of $184.9 \mathrm{~nm}$ radiation. The Dresher bottle containing the microcarriers was mounted on an orbital shaker (Lab Companion SK 300, Seoul, Korea) to ensure even radiation on PCL microcarrier surface. Microcarriers were treated under direct exposure to ozone and irradiation with UV (air). They were treated by ozone aerations \{direct exposure\}, UV irradiation \{air\}, and the combination of ozone aeration with UV irradiation $\left(\mathrm{UV} / \mathrm{O}_{3}\right)$ in accordance to the experimental design.

\section{Experimental design}

The experimental run was design by statistical software, Design Expert ${ }^{\circledR}$ 7.0. The influence of ozone concentration (Factor A), PCL sample amount (Factor B) and exposure time (Factor $\mathrm{C}$ ) on the concentration of carboxyl $(\mathrm{COOH})$ groups $(Y)$ deposited on the surface of microcarriers were evaluated using three levels faced centered composite design (FCCD) that require 20 formulations which include six replicates at the center point to represent process variations. This design was used to explore the quadratic response based on the second order polynomial model. The independent variables and their levels are presented in Table 1. A significant difference between the mean of three independent conditions was based on statistical analysis of variance (ANOVA).

Quantification of carboxylic (COOH) functional group on microcarriers' surface

Carboxylic $(\mathrm{COOH})$ functional groups introduced on the surface of PCL microcarriers were determined by Toluidine Blue O (TBO) assay. TBO solution ( $0.1 \%)$ was prepared by dissolving the TBO powder in $1 \mathrm{mM}$ $\mathrm{NaOH}$. PCL microcarrier $(1 \mathrm{~g})$ was placed in the $0.1 \%$ TBO solution and incubated at $40{ }^{\circ} \mathrm{C}$ in an incubator shaker (Infors HT, Bottmingen, Switzerland) at $400 \mathrm{rpm}$ for $30 \mathrm{~min}$. Using vacuum filtration, the PCL microcarriers were then washed with $1 \mathrm{mM}$ $\mathrm{NaOH}$ until the filtrate becomes colorless. This step ensures complete removal of any unbound dye that did not adsorb onto the surface. Collected microcarriers were placed in a tube containing $10 \mathrm{ml}$ of $20 \%$ SDS. The microcarriers were then incubated at $40{ }^{\circ} \mathrm{C}$ and shaken at $1300 \mathrm{rpm}$ for $30 \mathrm{~min}$ to desorb dyes from the microcarriers' surface. Once the dyes were desorbed from the surface, microcarriers were pelleted by centrifugation at $25^{\circ} \mathrm{C}, 12,000 \mathrm{rpm}$ for $15 \mathrm{~min}$. The dye intensity in the supernatant was then measured at $625 \mathrm{~nm}$ using a Multiskan ${ }^{\mathrm{TM}} \mathrm{GO}$ plate reader (Thermo Scientific, Waltham, MA, USA). A standard curve was generated using TBO concentrations of 5, 10, 20, 50, 75, 100, 150, and $200 \mu \mathrm{M}$. Calculation of TBO concentration was performed using the following equation, fitting the curve to a power plot:

Table 1 Factors and levels used in $2^{3}$ faced centered composite design (FCCD) for $\mathrm{UV} / \mathrm{O}_{3}$ treatment on PCL microcarriers surface

\begin{tabular}{llllll}
\hline Variable & Unit & Symbol & \multicolumn{2}{l}{ Uncoded level } & \\
\cline { 3 - 5 } & & & -1 & $42,492.8$ & $60,110.5$ \\
\hline Ozone concentration & ppm & A & 1 & 5.5 & $77,728.2$ \\
Sample amount & g & B & 30 & 60 & 10 \\
Exposure time & min & C & 90 \\
\hline
\end{tabular}


$\mathrm{A}=\mathrm{k} \times \mathrm{c}^{\mathrm{n}}$

where $A$ is the absorbance, $k$ and $n$ are constants, and $c$ is the concentration of TBO in the solution.

Gelatin immobilization

The $\mathrm{UV} / \mathrm{O}_{3}$-treated PCL microcarriers were covalently immobilized with gelatin using 1-ethyl-3-(3dimethylaminopropyl)-carbodiimide hydrochloride (EDAC) and $N$-hydroxysuccinimide (NHS) (EDAC/ NHS). The microcarriers were dispersed in $10 \mathrm{mg} / \mathrm{ml}$ EDAC and $5 \mathrm{mM}$ NHS in MES buffer ( $50 \mathrm{mM}, \mathrm{pH}$ ). The mixture was stirred and incubated at $4{ }^{\circ} \mathrm{C}$ for $24 \mathrm{~h}$. The microcarriers were collected by vacuum filtration and washed with $50 \mathrm{mM}$ MES buffer. The microcarriers were then dispersed in $100 \mathrm{ml}$ MES buffer and incubated for another $10 \mathrm{~min}$ at $4{ }^{\circ} \mathrm{C}$ to ensure the unbound cross-linkers were totally washed out. Next, the microcarriers were collected by vacuum filtration and washed with distilled water. After washing, the microcarriers were directly immersed in $10 \mathrm{mg} / \mathrm{ml}$ gelatin solution. The mixture was incubated at $37{ }^{\circ} \mathrm{C}$ in an incubator shaker (Infors HT) at $100 \mathrm{rpm}$ for $48 \mathrm{~h}$. After incubation, the microcarriers were collected by vacuum filtration and dispersed (washed) in PBS solution for $30 \mathrm{~min}$ in an incubator shaker. The washing steps were repeated in distilled water prior to final retrieval using vacuum filtration and drying at $30{ }^{\circ} \mathrm{C}$ overnight. The dry gelatin immobilized PCL microcarriers were stored in a desiccator until ready to use.

Quantitative measurement of immobilized gelatin on microcarrier

Immobilized gelatin was analyzed using the method suggested by Prockop and Udenfriend (1960) employing hydroxyproline collagen assay. First, $300 \mathrm{mg}$ of microcarriers were placed in $1.5 \mathrm{ml}$ screw cap tube containing $6 \mathrm{M}$ hydrochloric acid to hydrolyze the gelatin. The mixtures were then incubated at $95{ }^{\circ} \mathrm{C}$ for $22 \mathrm{~h}$. After incubation, the tubes were cooled to room temperature prior to centrifugation at $1300 \mathrm{rpm}$ for $10 \mathrm{~min}$. The supernatant $(35 \mu \mathrm{l})$ was pipetted into the appropriate well in a 96 well microplate and $75 \mu \mathrm{l}$ of buffer assay was added to each well. The microplate was covered with adhesive seal lid and incubated at $25{ }^{\circ} \mathrm{C}$ for $20 \mathrm{~min}$ with shaking (IKA). Detection reagent was prepared fresh according to the ratio of reagent $A$ and $B(2: 3)$. The detection reagent $(75 \mu \mathrm{l})$ was then added to each well and the microplate was again covered with an adhesive seal lid. The microplate was momentarily shaken to mix the solution before incubating at $60{ }^{\circ} \mathrm{C}$ for $60 \mathrm{~min}$. After the incubation, the microplate was cooled to room temperature prior to quantification of the amount of gelatin (hydroxyproline) at $570 \mathrm{~nm}$.

\section{Characterization}

Characterization of the physically optimized surface of PCL microcarriers was carried out to elucidate the improvement of wettability and biocompatibility of the microcarriers. The water contact angle was measured using Phoenix 300 Contact Angle analyzer (S.E.O. Co., Inc, Gyeonggi-do, Korea) by means of sessile drop method. The drops image was captured by a video camera and Surfaceware 8 software was used to calculate the contact angle from the shape of the water drop on the raw (untreated), $\mathrm{UV} / \mathrm{O}_{3}$ treated and gelatin coated PCL film. Next, the surface structure and morphology of PCL microcarriers were compared using scanning electron microscopy (Hitachi S3400 N, Tokyo, Japan). Surface chemistry of UV/ $\mathrm{O}_{3}$ treated PCL was analyzed by attenuated total reflectance (ATR) mode using Nicolet ${ }^{\mathrm{TM}} \mathrm{iS}^{\mathrm{TM}} 50 \mathrm{FT}$ IR spectrometer (Thermo Scientific) to observe the addition of functional oxygen groups after $\mathrm{UV} / \mathrm{O}_{3}$ treatment and the presence of amide bond on the gelation coated PCL microcarrier.

Microcarrier culture of $\mathrm{HaCaT}$ cells

\section{Monolayer cultivation}

Cryopreserved stocks of $\mathrm{HaCaT}$ cells were thawed and $1 \times 10^{5}$ cells $/ \mathrm{ml}$ were seeded into $25 \mathrm{~cm}^{2}$ tissue culture flasks containing complete DMEM medium supplemented with $10 \%(\mathrm{v} / \mathrm{v})$ FBS and $1 \%(\mathrm{v} / \mathrm{v})$ of $100 \mathrm{U} / \mathrm{ml}$ penicillin, $0.1 \mathrm{~g} / \mathrm{l}$ streptomycin. The flasks were incubated at $37{ }^{\circ} \mathrm{C}$ in a humidified $5 \% \mathrm{CO}_{2}$ atmosphere. Upon reaching $80 \%$ confluence, cells were detached using accutase and subcultured at the same cell density in $175 \mathrm{~cm}^{2}$ culture flask. Cells were fed every other day by replacing $100 \%$ of the spent medium with fresh medium. Subsequently, cells were detached using accutase and then resuspended in the 
culture medium as described above, for use in microcarrier culture.

\section{Microcarrier preparation}

Polycaprolactone (PCL) microcarrier was subjected to sterilization using 70\% ethanol. The microcarriers were dispersed in PBS, and once the microcarriers have settled at the bottom, the supernatant was decanted and the microcarriers were washed twice in $70 \%$ ethanol solution prior to overnight incubation in $70 \%$ (v/v) ethanol (50-100 ml per gram of microcarrier). The ethanol solution was removed and the microcarriers were rinsed three times in sterile PBS $(50 \mathrm{ml} / \mathrm{g}$ microcarrier) and equilibrated in culture medium (50 ml/g microcarrier) before use.

\section{Microcarrier culture cultivation}

Inoculum for spinner flasks was obtained from static monolayer growth in $175 \mathrm{~cm}^{2}$ tissue culture flasks. Spent medium was discarded and the flask was washed twice with PBS and then incubated for $15 \mathrm{~min}$ in accutase until complete cell removal from the flask's surface. The accutase was inactivated by the addition of fresh culture medium to the cell suspension. The suspension was then centrifuged at $100 \times g$ for $5 \mathrm{~min}$. The supernatant was discarded and the remaining pellet was resuspended in $30 \mathrm{ml}$ fresh complete medium. Cell concentration was determined using Neubauer hemocytometer under an inverted phase microscope (Olympus CK40, Tokyo, Japan). Five hundred milliliter spinner vessel (BellCo, Vineland, NJ, USA) with $200 \mathrm{ml}$ working volume was coated with $5 \%$ silicon oil in ethyl acetate (to prevent microcarrier from attaching to the inner surface). PCL microcarriers $(3 \mathrm{~g} / \mathrm{ml})$ suspended in $50 \mathrm{ml}$ culture medium and cells at a concentration of $1.5 \times 10^{5} \mathrm{cell} / \mathrm{ml}$ were inoculated in the spinner flask and culture medium was added to a final volume of $200 \mathrm{ml}$. Samples $(2 \mathrm{ml}$ ) of cell suspension were taken every $12 \mathrm{~h}$ and analyzed for cell viability and morphology.

\section{Sampling and cell counting}

One millilitre of microcarriers culture was aseptically pipetted out from the spinner flask culture and placed into a $15 \mathrm{ml}$ tube. The microcarriers were allowed to settle. Supernatant was discarded. Microcarriers were washed twice with PBS before treatment with Accutase and the tube was incubated in $\mathrm{CO}_{2}$ incubator for $15 \mathrm{~min}$ at $37^{\circ} \mathrm{C}$. After $15 \mathrm{~min}$ the mixture was gently flushed to detach the immobilised cells. The concentration of cells in the suspension was determined using a haemacytometer with the aid of trypan blue. Twenty microlitres of cell suspension were mixed with an equal volume of trypan blue dye. Ten microlitres of the mixture were placed on the haemacytometer and allowed to spread by capillary action. Cells were counted under an inverted microscope and concentration of cells (cells/ml) was calculated using Eq. 2.

$c=n / v$

$c=$ cell concentration (cells $/ \mathrm{ml}), n=$ number of cells, $v=$ volume counted $(\mathrm{ml})$

Standard heamacytometers used have the depth of chamber of $1 \mathrm{~mm}$ and the area of the central grid is $1 \mathrm{~mm}^{2}$. Therefore $v=0.1 \mathrm{~mm}^{3}$. The formula then becomes

$c=n / 1 \times 10^{-4}$

or

$c=n \times 10^{4}$

If the cells were too concentrated, the cell suspension was diluted and the dilution factor was added in the calculation as follows:

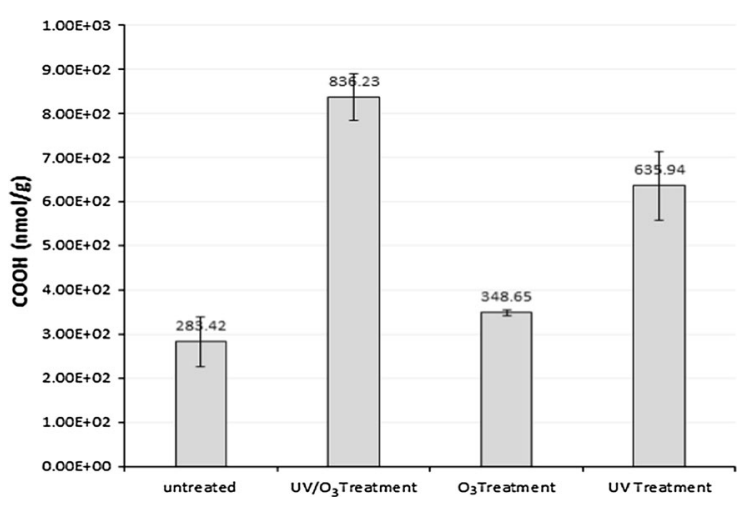

Fig. 1 Amount of carboxylic acid (COOH) functional group introduced on the surface of untreated microcarrier and microcarrier treated with either $\mathrm{UV} / \mathrm{O}_{3}$ treatment, ozone aeration (only) treatment, UV irradiation (only) treatment, respectively. Oxygen flow rate $(2 \mathrm{lpm})$, sample amount $(1 \mathrm{~g})$, exposure time $(10 \mathrm{~min})$ and $\mathrm{UV}$ intensity $\left(22 \mathrm{~mW} / \mathrm{cm}^{2}\right)$ were held constant for the respective treatment 
$c=n \times$ dilution factor $\times 10^{4}$

\section{Results and discussion}

Effect of surface modification by ultraviolet (UV), ozone, and combination of $\mathrm{UV} / \mathrm{O}_{3}$

The amount of carboxylic acid $(\mathrm{COOH})$ group introduced on the surface of microcarriers treated with either UV, ozone, and combination of UV and ozone $\left(\mathrm{UV} / \mathrm{O}_{3}\right)$ treatment was measured (Fig. 1). The amount of $\mathrm{COOH}$ in the PCL sample was highest in the combination treatment of $\mathrm{UV} / \mathrm{O}_{3}(836.32 \mathrm{nmol} / \mathrm{g})$ as compared to untreated PCL $(283.42 \mathrm{nmol} / \mathrm{g})$, ozone treatment $(348.65 \mathrm{nmol} / \mathrm{g})$ and UV treatment $(635.94 \mathrm{nmol} / \mathrm{g})$. The high amount of surface $\mathrm{COOH}$ is expected to improve the wettability of the PCL microcarriers.

$\mathrm{UV} / \mathrm{O}_{3}$ treatment is a practical technique to modify the surface of PCL microcarrier to provide preferable surface charge density for adsorption of proteins and anchoring dependent cells (Zhou et al. 2013). Ozone did not measurably change the polymer surface unless in the presence of energy (such as heat or light) that can degrade the ozone into molecular oxygen and oxygen atom which then reacts with the polymer surface (Callen et al. 1995). Meanwhile, UV irradiation resulted in scission of the ester linkage resulting in the increase of surface oxygen content on the polymer surface; thus increased $\mathrm{COOH}$ group on the PCL surface in the presence of air (Callen et al. 1995; Murakami, Fukushima and Hirano 2003). However, due to limitation of oxygen in atmospheric condition, the reaction is minimal. In the $\mathrm{UV} / \mathrm{O}_{3}$ combination treatment, the effect is more pronounced where UV radiation activated and degraded the ozone into molecular oxygen and an oxygen atom, thus allowing ozone to react with the polymer surface.

Interaction of carboxylic functional group $(\mathrm{COOH})$ and amount of immobilized gelatin

Recent investigations have demonstrated that immobilization of certain biologically active molecules on polymer surface is an effective strategy to promote cell adhesion and proliferation (Darain et al. 2010; Yuan et al. 2012; Zhu et al. 2002). For instance, gelatin was

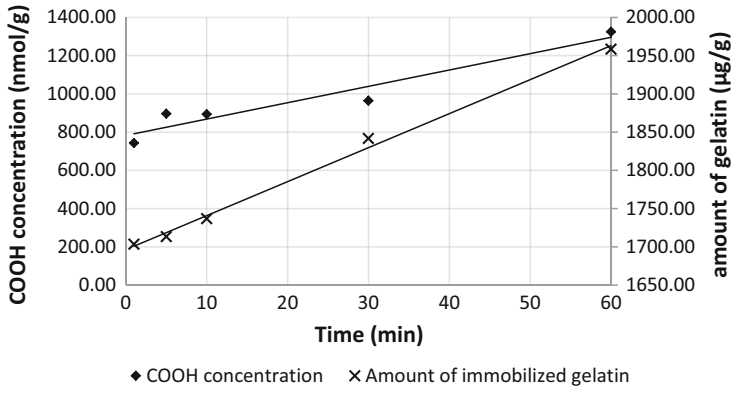

Fig. 2 Interaction between carboxyl $(\mathrm{COOH})$ concentration on microcarrier surface and amount of gelatin immobilized. Kim et al. (2009) found that carboxyl functional group increased proportionally with the exposure time of oxygen plasma treatment. Subsequently, the efficiency of the protein immobilization on the treated surface was increased thus generating functional amine $\left(\mathrm{NH}_{2}\right)$ group for cell adhesion

covalently immobilized on the PCL surface through the formation of a peptide bond between carboxylic acid and amine $\left(\mathrm{NH}_{2}\right)$ group from gelatin (Zhu et al. 2002). Figure 2 shows a direct proportional interaction between $\mathrm{COOH}$ and amount of gelatin immobilized on the surface of the microcarrier. The concentration of $\mathrm{COOH}$ increased with time, subsequently, the amount of gelatin increased as the concentration of $\mathrm{COOH}$ increased.

Optimization of process conditions of $\mathrm{UV} / \mathrm{O}_{3}$ treatment

Based on the results shown in the previous sections, the $\mathrm{UV} / \mathrm{O}_{3}$ combination treatment was found to be superior to the UV or ozone treatment alone. Therefore, the optimization of $\mathrm{UV} / \mathrm{O}_{3}$ process conditions using central composite design was carried out with the aim to maximize the concentration of functional carboxylic acid $(\mathrm{COOH})$ group introduced on the PCL microcarrier surface to enhance immobilization of gelatin. Table 2 shows the combined effects of three variables namely ozone concentration (A), the amount of samples (B) and exposure time (C) on the concentration of $\mathrm{COOH}$. Based on the regression analysis, the second order polynomial model for concentration of $\mathrm{COOH}$ ( $\mathrm{Y} \mathrm{nmol} / \mathrm{g}$ ) was obtained as a function of variables and can be represented as follows:

$$
\begin{aligned}
\mathrm{Y}= & 1432.96+23.10 \mathrm{~A}+196.63 \mathrm{~B}+169.87 \mathrm{C} \\
& -3.68 \mathrm{~A}^{2}-208.58 \mathrm{~B}^{2}-269.67 \mathrm{C}^{2} \\
& +18.34 \mathrm{AB}+30.85 \mathrm{AC}-59.61 \mathrm{BC}
\end{aligned}
$$


Table 2 Measured and predicted carboxyl $(\mathrm{COOH})$ concentration in the experiments obtained by faced centered composite design (FCCD)

\begin{tabular}{|c|c|c|c|c|c|}
\hline \multirow[t]{2}{*}{ Run } & \multicolumn{3}{|c|}{ Experimental factors } & \multicolumn{2}{|c|}{$\mathrm{Y}(\mathrm{COOH}$ conc $)(\mathrm{nmol} / \mathrm{g})$} \\
\hline & $\mathrm{A}(\mathrm{ppm})$ & B (gram) & $\mathrm{C}(\min )$ & Measured & Predicted \\
\hline 1 & 60110.52 & 5.5 & 30 & 1044.95 & 993.43 \\
\hline 2 & $42,492.8$ & 5.5 & 60 & 1398.22 & 1406.19 \\
\hline 3 & $42,492.8$ & 1 & 30 & 510.99 & 551.02 \\
\hline 4 & $42,492.8$ & 10 & 30 & 1046.13 & 1026.83 \\
\hline 5 & $77,728.24$ & 5.5 & 60 & 1464.57 & 1452.39 \\
\hline 6 & $60,110.52$ & 1 & 60 & 1117.19 & 1027.76 \\
\hline 7 & $42,492.8$ & 10 & 90 & 1213.98 & 1185.64 \\
\hline 8 & $42,492.8$ & 1 & 90 & 948.64 & 948.28 \\
\hline 9 & $77,728.24$ & 10 & 30 & 1046.60 & 1048.01 \\
\hline 10 & $60,110.52$ & 5.5 & 60 & 1452.50 & 1432.96 \\
\hline 11 & $60,110.52$ & 5.5 & 60 & 1495.92 & 1432.96 \\
\hline 12 & $77,728.24$ & 1 & 90 & 999.16 & 1019.51 \\
\hline 13 & $77,728.24$ & 1 & 30 & 469.46 & 498.85 \\
\hline 14 & $60,110.52$ & 5.5 & 60 & 1445.57 & 1432.96 \\
\hline 15 & $60,110.52$ & 5.5 & 60 & 1476.90 & 1432.96 \\
\hline 16 & $77,728.24$ & 10 & 90 & 1369.19 & 1330.21 \\
\hline 17 & $60,110.52$ & 5.5 & 60 & 1481.53 & 1432.96 \\
\hline 18 & $60,110.52$ & 10 & 60 & 1335.80 & 1421.01 \\
\hline 19 & $60,110.52$ & 5.5 & 90 & 1285.86 & 1333.17 \\
\hline 20 & $60,110.52$ & 5.5 & 60 & 1236.93 & 1432.96 \\
\hline
\end{tabular}

$\mathrm{A}=$ Ozone concentration, $\mathrm{B}=$ Amount of sample, $\mathrm{C}=$ Exposure time

The optimum process conditions were as in Run 11 with ozone concentration of $60110.52 \mathrm{ppm}$, amount of samples of $5.5 \mathrm{~g}$ and exposure time at $60 \mathrm{~min}$ with carboxyl concentration of $1495.92 \mathrm{nmol} / \mathrm{g}$

Table 3 ANOVA for response surface quadratic model

\begin{tabular}{lrrr}
\hline Source & Sum of squares & F-value & $p$ value \\
\hline Model & $1,648,458.77$ & 25.03 & $<0.0001$ \\
A-ozone concentration & 5337.00 & 0.73 & 0.4130 \\
B-amount of sample & $38,6621.53$ & 52.84 & $<0.0001$ \\
C-exposure time & $288,553.51$ & 39.44 & $<0.0001$ \\
AB & 2689.67 & 0.37 & 0.5578 \\
AC & 7612.82 & 1.04 & 0.3317 \\
BC & $28,429.07$ & 3.89 & 0.0770 \\
$\mathrm{~A}^{2}$ & 37.16 & 0.005 & 0.9446 \\
$\mathrm{~B}^{2}$ & $11,9636.98$ & 16.35 & 0.0023 \\
$\mathrm{C}^{2}$ & $199,979.83$ & 27.33 & 0.0004 \\
\hline $\mathrm{R}^{2}=0.9575 ;$ Adj $\mathrm{R}^{2}=0.9193 ;$ Pred $\mathrm{R}^{2}=0.8433$ &
\end{tabular}

$\mathrm{COOH}$ concentrations were found to be in the range of $469.46 \mathrm{nmol} / \mathrm{g}$ (run 13) to $1495.92 \mathrm{nmol} / \mathrm{g}$ (run 11) (Table 2). The optimum process conditions were as in
Run 11 with ozone concentration of $60110.52 \mathrm{ppm}$, amount of samples of $5.5 \mathrm{~g}$ and exposure time at $60 \mathrm{~min}$ with carboxyl concentration of $1495.92 \mathrm{nmol} / \mathrm{g}$.

The analysis of variance (ANOVA) of the model is shown in Table 3. The quality of the model can be analyzed by several measures. The first measure is the Fisher ratio (F-value) which demonstrates the significance of the model. F-value of the model (25.03) indicates that the model was highly significant and effect of factors was real (Anderson and Whitcomb 2015). The probability ( $p$ value) is also a measure of the significance of a regression model and each parameter that contributes to the model equation (Hinkelmann and Kempthorne 2008). The very low probability value $(p<0.0001)$ as seen in Table 3 ensures the valid measures of variation in the data about its mean. The smaller the value indicates the higher the significance of the model and the higher the 
relevance of the corresponding parameters contribution to the model. Model coefficients of all linear terms and quadratic terms except for ozone concentration were found to be significant with $p$ value of $<0.0001$ and $<0.05$, respectively. Linear terms for the amount of samples (B) and exposure time (C) show the highly significant effects to the model $(p<0.0001)$. However, no interaction terms were significant. The significance of the model was also evaluated by lack-of-fit test, which measures the failure of the model to represent the data in the experimental domain at points that were not included in the regression (Gomathi and Neogi 2009). Lack of fit of the model was found to be insignificant which is strongly desirable for the model.

In the present study, limited range of ozone concentration available from the ozone generator machine might contribute to the poor relationship between ozone concentration and concentration of carboxyl group deposited on the surface. This constraint was also encountered by Macmanus et al. (1999) where no clear relationship can be seen between ozone concentration and wettability of polymer surface.

The coefficient of determination, $\mathrm{R}^{2}=0.9575$ estimated for the above equation implies that $95.75 \%$ of the variability in the response $(\mathrm{COOH}$ concentration) could be explained by the model and that only $4 \%$ of total variation was not explained by the model. The adjusted $\mathrm{R}^{2}=0.9193$ was also found to be very high which is particularly useful when comparing models with a different number of terms, therefore, indicating a high degree of significance of the model (Anderson and Whitcomb 2015).

\section{The interactive effects of process condition on gelatin immobilization}

Three-dimensional response surface and two-dimensional contour plots of the parameter interactions which were plots to determine the optimal values of each parameters. The maximum response of the parameters and the optimum process conditions could be identified by obtaining an elliptical contour plot which means the perfect interaction between independence variable is achieved (Anderson and Whitcomb 2015). Figure 3 shows the effects of interaction between ozone concentration, exposure time and amount of samples on concentration of carboxylic acids introduced on the microcarrier surface.

These plots show that the $\mathrm{COOH}$ concentration increase with increase in factor level up to center points and then decreased for exposure time and amount of samples. The decrease in the $\mathrm{COOH}$ concentration as the amount of the sample increased after it reached maximum would be due to the less probability of the particle to be exposed to UV light and ozone caused by tight and limited space. The best interaction (elliptical contour plot) was between independent variables of exposure time and the amount of samples.

Amount of gelatin immobilized on $\mathrm{UV} / \mathrm{O}_{3}$ treated microcarrier (gelatin coated PCL)

The introduction of oxygen functional group onto PCL microcarrier not only improved the hydrophilicity, indeed it provides a favorable site for biomacromolecules such as protein, peptide, polysaccharide or growth factor. The immobilization of gelatin onto the modified surface was achieved through covalent bonding using zero-length crosslinker as described in materials and methods section. The $\mathrm{UV} / \mathrm{O}_{3}$ treated microcarriers obtained from the optimization work were used in this current phase of study and subsequent work.

Table 4 shows the amount of gelatin being immobilized onto the microcarrier before and after $\mathrm{UV} / \mathrm{O}_{3}$ treatment. The measurement was based on the detection of hydroxyproline from the hydrolyzed gelatin that is immobilized on the microcarrier surface. There was an increase in concentration of gelatin immobilized on the microcarrier surface after the optimization of the process condition by $91.6 \%$ of the untreated PCL microcarrier.

Characterization of $\mathrm{UV} / \mathrm{O}_{3}$ treated PCL microcarrier and gelatin coated PCL microcarrier

To facilitate further discussion, the gelatin coated-UV/ $\mathrm{O}_{3}$ treated microcarrier is referred to as 'gelatin coated PCL'. In order to further clarify the effects of oxidization and introduction of functional groups on the surface of PCL microcarrier, the hydrophilicity and composition of the treated surface were investigated. Surface contact angle measures the hydrophilicity of the treated microcarrier and attenuated 

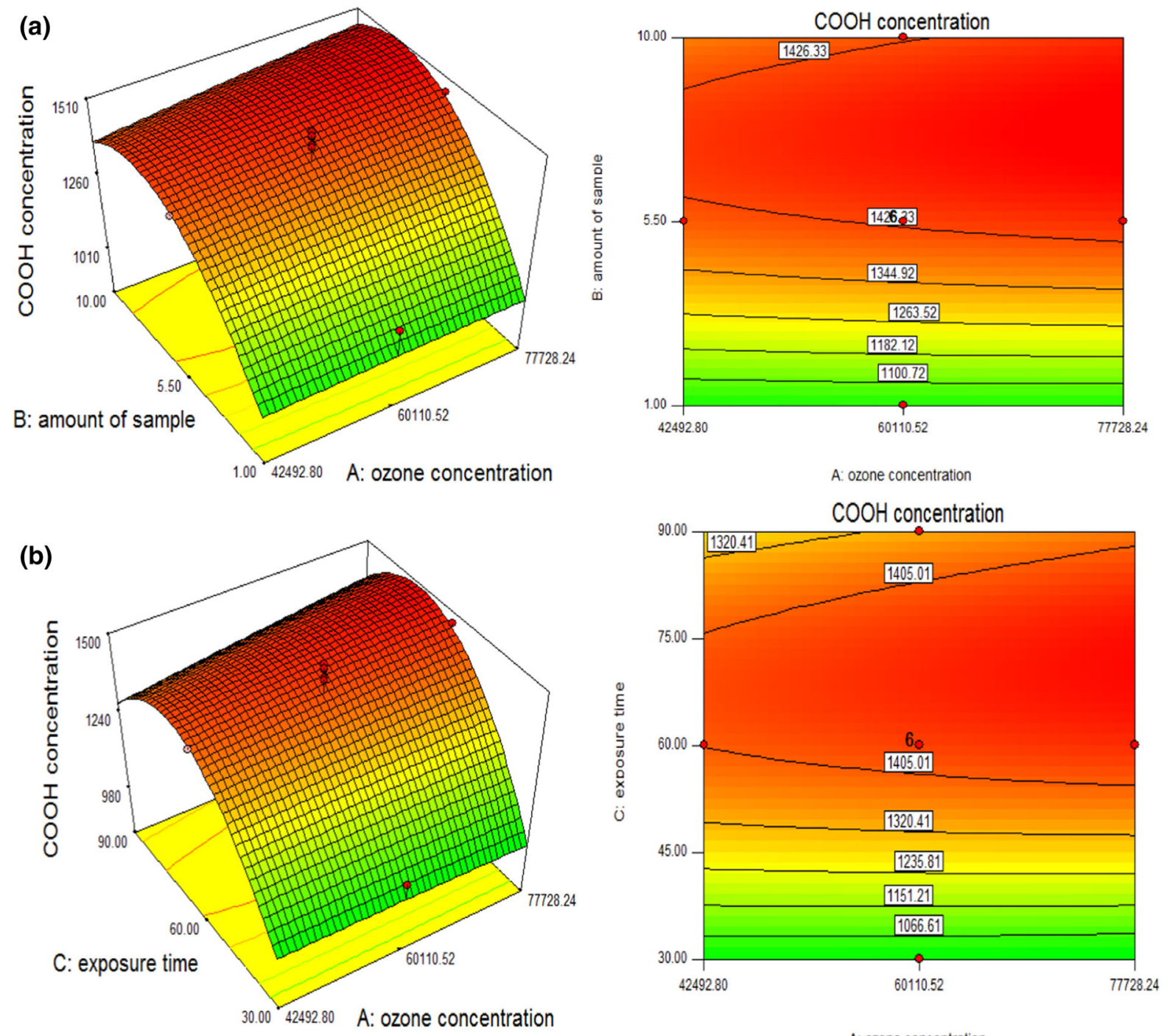

(c)
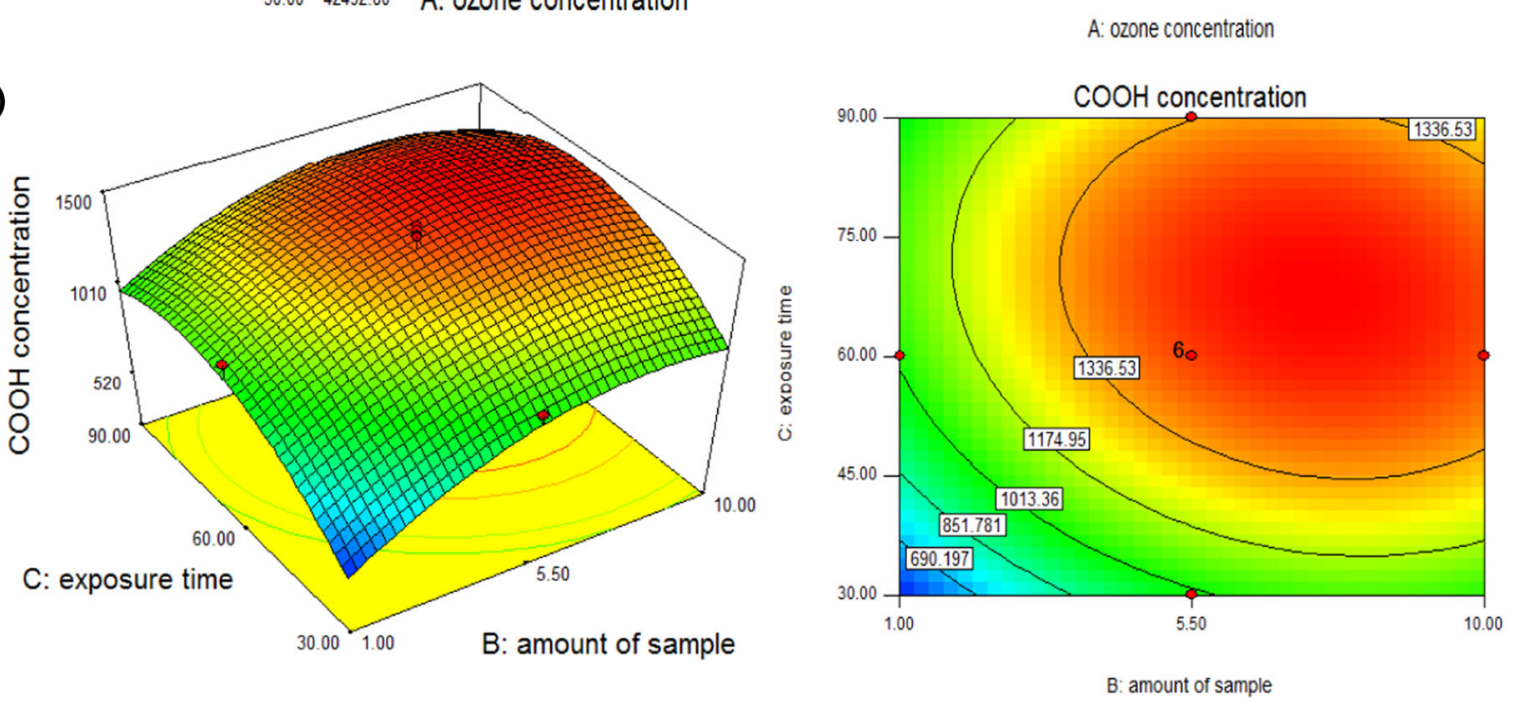
4 Fig. 3 3-D response surface and 2-D contour plot of interaction between a ozone concentrations and amount of samples; b exposure time and ozone concentration; c exposure time and amount of samples

Table 4 Concentration of absorbed gelatin on untreated PCL microcarrier and $\mathrm{UV} / \mathrm{O}_{3}$ treated PCL microcarrier

\begin{tabular}{lcl}
\hline Microcarrier & $\begin{array}{l}\text { Concentration of } \\
\text { immobilized } \\
\text { gelatin }(\mu \mathrm{g} / \mathrm{g})\end{array}$ & $\%$ increased \\
\hline Untreated PCL & $26.83 \pm 3.0$ & NA \\
$\mathrm{UV} / \mathrm{O}_{3}$ treated & $320.00 \pm 0.9$ & 91.6 \\
\hline
\end{tabular}

Table 5 Contact angle values and surface energy of untreated, $\mathrm{UV} / \mathrm{O}_{3}$ treated and $\mathrm{UV} / \mathrm{O}_{3}$ treated and gelatin coated $\mathrm{PCL}$ microspheres

\begin{tabular}{lll}
\hline Microcarrier & $\begin{array}{l}\text { Contact } \\
\text { angle }\left(^{\circ}\right)\end{array}$ & $\begin{array}{l}\text { Surface energy } \\
\left(\mathrm{mJ} / \mathrm{m}^{2}\right)\end{array}$ \\
\hline Untreated PCL & 86.93 & 24.94 \\
$\mathrm{UV} / \mathrm{O}_{3}$ treated PCL & 69.34 & 41.12 \\
Gelatin coated PCL & 49.34 & 61.28 \\
\hline
\end{tabular}

reflection-Fourier transform infra red (ATR-FTIR) confirmed the addition of functional groups on the microcarrier surface. The morphology of microspheres surface was studied by scanning electron microscope (SEM).

\section{Contact angle measurement}

The hydrophilic property of PCL microcarrier was evaluated by water contact angle that utilized deionized water as test liquid and by measuring the binding energy. The wettability of $\mathrm{UV} / \mathrm{O}_{3}$ treated film was compared to the untreated and gelatin coated film. Table 5 shows the water contact angle values and surface energy of untreated PCL film, $\mathrm{UV} / \mathrm{O}_{3}$ treated PCL film and gelatin coated PCL film. Treatment was made by relative measurement under similar condition as for microcarriers.

From Table 5 the value of contact angle of untreated microcarrier $\left(86.93^{\circ}\right)$ imposed a relatively hydrophobic behavior. The angle was consequently decreased to $69.34^{\circ}$ after $\mathrm{UV} / \mathrm{O}_{3}$ treatment thus increased the surface energy from 24.94 to
$41.12 \mathrm{~mJ} / \mathrm{m}^{2}$. This could be due to the incorporation of functional oxygen-containing groups like $\mathrm{O}-\mathrm{C}=\mathrm{O}$, $\mathrm{C}=\mathrm{O}, \mathrm{C}-\mathrm{O}$ and $\mathrm{OH}$ (Darain et al. 2010) on the surface of the microcarrier. According to Gomathi and Neogi (2009) an increase in surface energy is due to the incorporation of the polar components on the surface by the presence of the polar groups, electric charges and free radicals. The introduction of functional and polar components on the PCL microcarrier surface not only improved its hydrophilicity but may also accommodate biomolecules components such as protein and cell growth factors to make the surface more biocompatible for cell growth and proliferation (Zhu et al. 2002). Drastic decrease in contact angle from $69.34^{\circ}$ to $49.34^{\circ}$ for gelatin coated PCL microcarrier was observed. This indicates further improvement in hydrophilicity as compared to $\mathrm{UV} / \mathrm{O}_{3}$ treated $\mathrm{PCL}$ microcarrier which could be due to the presence of large amount of amino terminal and carboxyl groups (Yuan et al. 2012).

\section{ATR-FTIR analysis}

Attenuated total reflectance Fourier transformed infrared spectroscopy (ATR-FTIR) analysis was performed to determine the surface elements of PCL microcarriers. The peaks at 1723, 1175 and $1230 \mathrm{~cm}^{-1}$ (Fig. 4) are the signature peaks of polyesters which correspond to $\mathrm{C}=\mathrm{O}, \mathrm{C}-\mathrm{O}-\mathrm{C}$ and $\mathrm{C}-$ $\mathrm{C}$, respectively, in the IR spectra (Kemala et al. 2012).

Interestingly, Fig. 4 shows the presence of a new peak in $\mathrm{UV} / \mathrm{O}_{3}$ PCL spectra at wave number $3445 \mathrm{~cm}^{-1}$. This suggests the change in $\mathrm{O}-\mathrm{H}$ group absorption resulted from oxidation process by $\mathrm{UV} / \mathrm{O}_{3}$ could introduce $\mathrm{O}-\mathrm{H}$ group in the main chain of PCL (Sabino 2007). Meanwhile, marked broadening in the region of $1600-1750 \mathrm{~cm}^{-1}$ could be attributed to the free acids, modification of chemical environment around the carbonyl group or the formation of vinyl groups (Wu 2002). Subsequently, the successful immobilization of gelatin onto the $\mathrm{UV} / \mathrm{O}_{3}$ treated PCL surface could be deduced by the presence of a broadband at $3300 \mathrm{~cm}^{-1}$, possibly due to the overlapping of stretching vibrations of a hydroxyl group (O$\mathrm{H})$ and of an amine group $(\mathrm{N}-\mathrm{H})$. Increase in the relative intensity of amide I band (at $1654 \mathrm{~cm}^{-1}$ ) and amide II at $\left(1544 \mathrm{~cm}^{-1}\right)$ (Yuan et al. 2012) also attributed to the successful gelatin immobilization. 


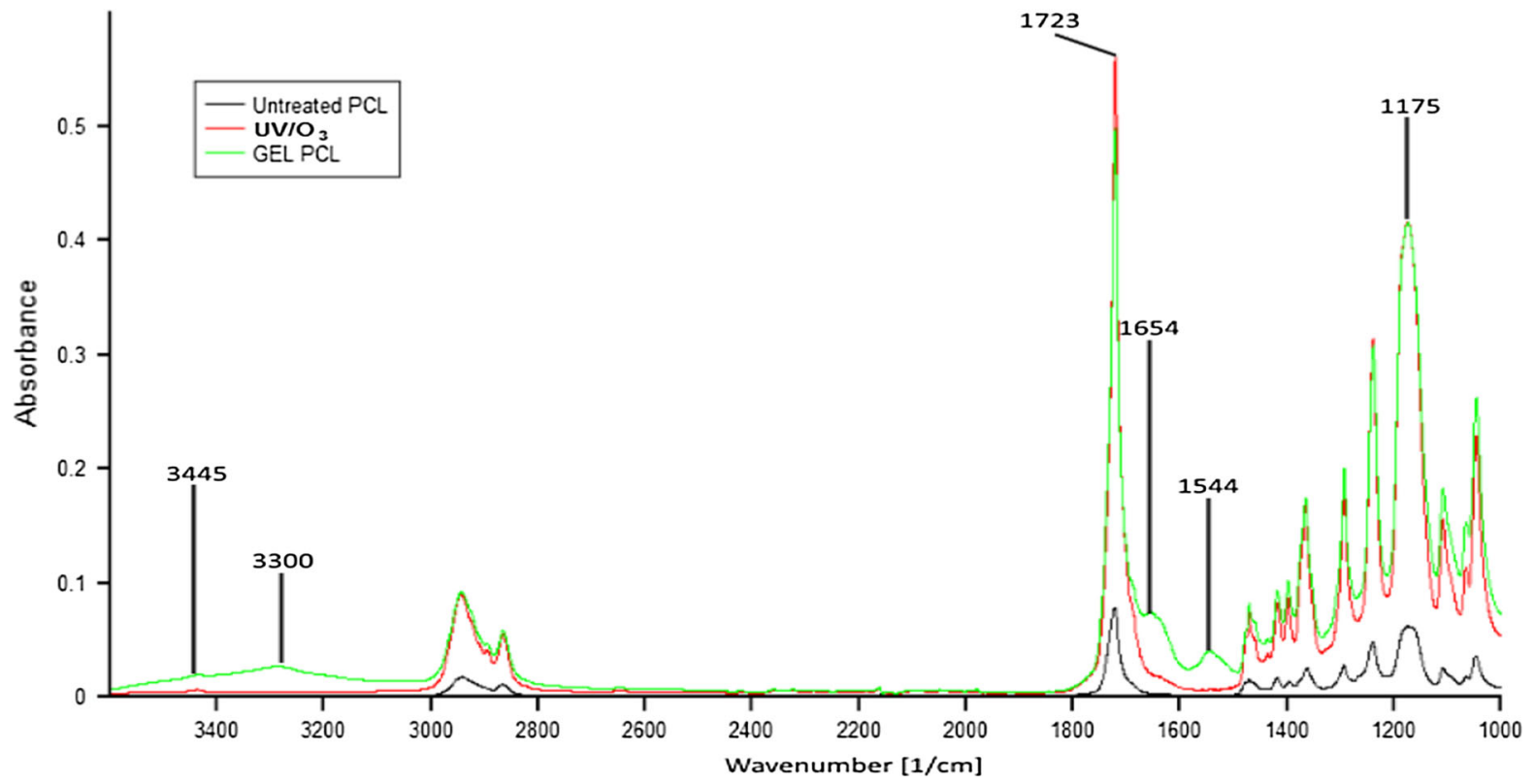

Fig. 4 ATR-FTIR spectra of untreated PCL, UV/O 3 treated PCL (UV/O 3 PCL) and gelatin coated PCL (GEL PCL)

\section{SEM analysis}

The morphology of the PCL microcarrier was examined by SEM, as displayed in Fig. 5. The microcarriers were observed to be spherical with a uniform particle size in the range of $100-150 \mu \mathrm{m}$. The surface of untreated PCL (Fig. 5a) appears to be smoother than the surface of $\mathrm{UV} / \mathrm{O}_{3}$ treated PCL microcarrier (Fig. 5b). Upon $\mathrm{UV} / \mathrm{O}_{3}$ treatment the surface appears to crease and have plenty of holes which can be clearly seen in Fig. 5d.

Further, microcarriers coated with gelatin exhibited rather smooth surface as compared to $\mathrm{UV} / \mathrm{O}_{3}$ treated PCL (Fig. 5c, f). The creases were covered by gelatins that were immobilized onto the surface through covalent bonding with intermediate crosslink. The immobilization was uniform over the microcarrier surface and this may help improve the biocompatibility of the microcarrier (Hong et al. 2005).

HaCaT growth on microcarrier culture

The importance of surface functionalization and wettability in microcarrier cell culture has been studied by many researchers due to its importance for cell growth and proliferation (Goh et al. 2013;
Teare et al. 2000; Yanagisawa et al. 2006). The different types of PCL-based microcarriers studied in this present research (untreated PCL microspheres, $\mathrm{UV} / \mathrm{O}_{3}$ treated PCL and gelatin coated PCL microcarrier) were further tested for their performance to support the attachment and growth of HaCatT cells. Figure 6 shows the growth kinetics of $\mathrm{HaCaT}$ cells on untreated PCL microcarrier, $\mathrm{UV} / \mathrm{O}_{3}$ treated $\mathrm{PCL}$ microcarrier and gelatin coated $\mathrm{PCl}$ microcarrier.

Microcarriers $(3 \mathrm{~g} / \mathrm{l})$ were used to support cell growth in $500 \mathrm{ml}$ spinner vessels with $200 \mathrm{ml}$ medium (working volume) at a seeding concentration of $1.5 \times 10^{5}$ cells $/ \mathrm{ml}$ for each type of microcarrier, respectively. Low agitation (30 rpm) was applied for the first $2 \mathrm{~h}$ to allow cells to attach and distribute efficiently. Subsequently, the agitation speed was increased to $60 \mathrm{rpm}$ to maintain homogeneity of suspension culture, ensure good gas exchange and prevent aggregation of the microcarrier.

Cell attachment and growth are influenced by the types of the surface of a microcarrier (Goh et al. 2013; Murakami et al. 2005; Yusilawati et al. 2010). Figure 6 shows that the culture of untreated (raw) PCL was observed to have slight cell loss within $12 \mathrm{~h}$ of inoculation. The loss might be due to the low efficiency of cell attachment and spreading on the 

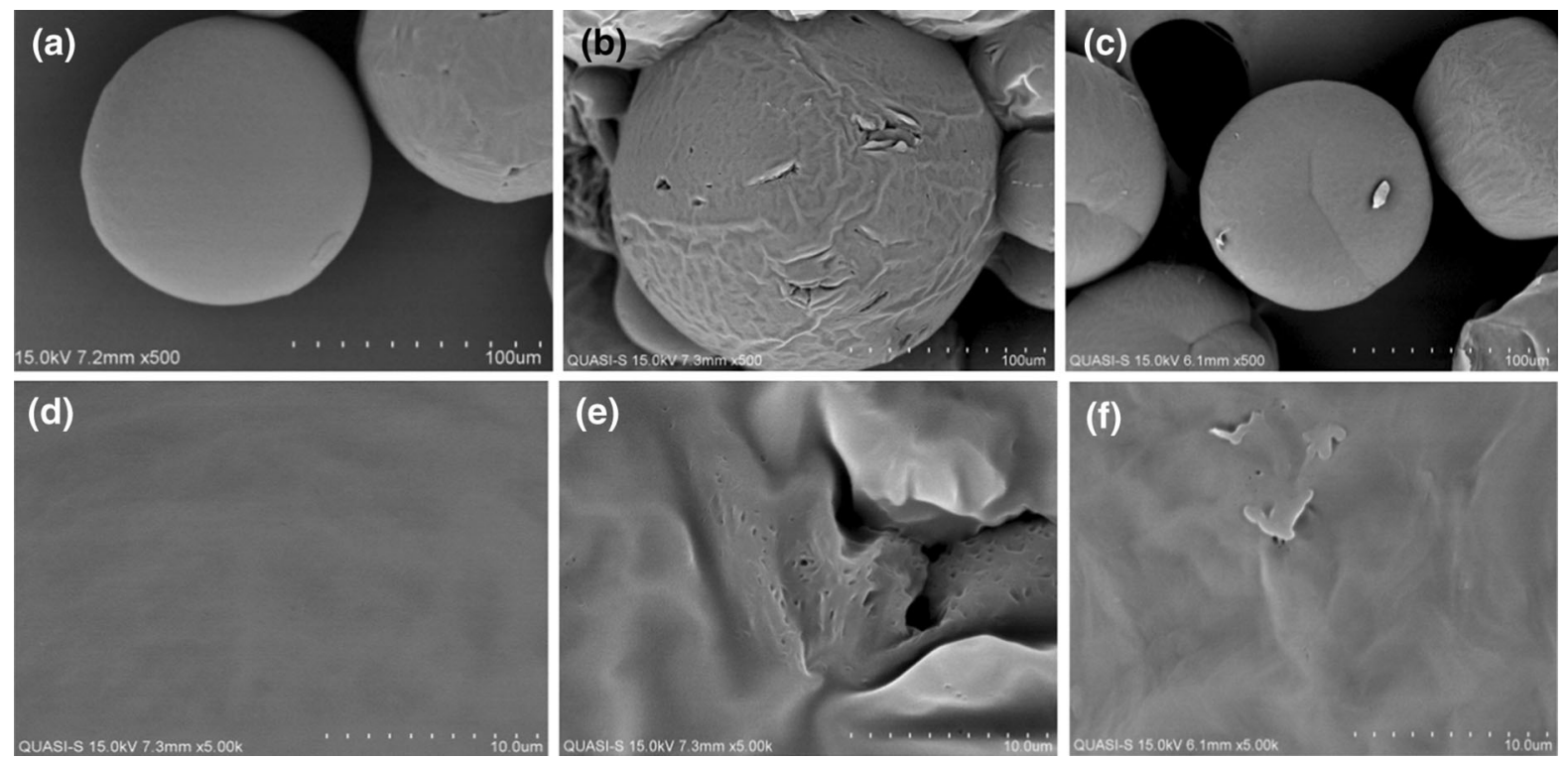

Fig. 5 SEM images show the untreated PCL microcarrier (a), UV/O ${ }_{3}$ treated PCL microcarrier (b), and gelatin coated PCL microcarrier $(\mathbf{c})$. $\mathbf{d}, \mathbf{e}$ and $\mathbf{f}$ are higher magnification of $(\mathbf{a}-\mathbf{c})$, respectively

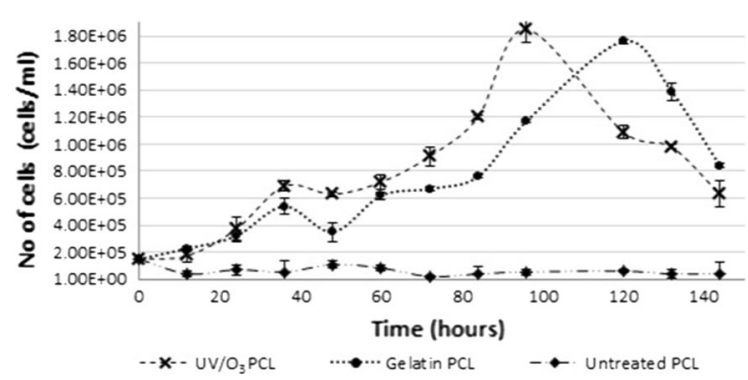

Fig. 6 Growth kinetics of human keratinocytes cells (HaCaT) on different microcarriers cultured in stirred spinner vessels (x) $\mathrm{UV} / \mathrm{O}_{3} \mathrm{PCL}$, (filled circle) gelatin immobilized, (filled diamond) untreated PCL. Result were based on three independent experiment $(\mathrm{n}=3$, mean $\pm \mathrm{SD})$

hydrophobic, uncharged microcarrier surface (Goh et al. 2013). It was also observed that there was no growth in cultures on untreated PCL (Table 6).

Based on growth kinetics data (Table 6), $\mathrm{UV} / \mathrm{O}_{3}$ treated microcarriers provide better surface for $\mathrm{HaCaT}$ cell attachment. The maximum cell concentration on $\mathrm{UV} / \mathrm{O}_{3} \mathrm{PCL}$ was $18.5 \pm 9.8$ cells $/ \mathrm{ml}$ with a growth rate of $0.0299 \mathrm{~h}^{-1}$, which is observed to be slightly higher as compared to gelatin coated microcarrier with $17.6 \pm 14.1 \mathrm{cell} / \mathrm{ml}$ maximum cell concentration and a cell growth rate of $0.0257 \mathrm{~h}^{-1}$. Moreover, the cells grown on $\mathrm{UV} / \mathrm{O}_{3}$ PCL reached a doubling time of $23.18 \mathrm{~h}$ as compared to those grown on gelatin coated PCL (doubling time at $27.02 \mathrm{~h}$ ).
The difference in $\mathrm{HaCaT}$ cell growth rate between the three types of microcarrier could be due to the absorption of different serum proteins (Jacobson and Ryan 1982). There are three different microcarriers with different surface properties (charged, uncharged, gelatin coated), which absorb different serum proteins that lead to differences in cell adhesion for each microcarrier. Yet there is very limited information on the interaction between serum proteins and the culture surface (Teare et al. 2001). There are two major classes of proteins in serum, fibrous and globular types (GE Healthcare handbook 2005). Globular proteins (albumin and $\gamma$-globulin (IgG)), types of non-adhesive protein, prevent cell attachment by blocking expression of fibrous protein or become competitively absorbed to the polymer surface. Meanwhile, fibrous proteins (fibronectin, vitronectin, type I collagen, hormone, growth factor and spreading factor) play a significant role in binding of a cell to the surface since they contain common sequences to all adhesive proteins, the ARG-GLY-ASP (RGD) sequence.

In the presence of $10 \%$ serum in the culture medium, as discussed by Teare et al. (2001), the hydrophobic surface is likely to absorb the nonadhesive proteins or the proteins that possess unfavorable conformation for the cells to attach. In contrast, as for the surface containing oxygen functional groups $\left(\mathrm{UV} / \mathrm{O}_{3}\right)$, the surfaces are made 
Table 6 Growth kinetics of HaCaT cells on different types of microcarrier

\begin{tabular}{lccc}
\hline Microcarrier & Maximum cell concentration $\left(\times 10^{5}\right.$ cells/ml $)$ & Growth rate, $\mu\left(\mathrm{h}^{-1}\right)$ & Doubling time, $\mathrm{t}_{\mathrm{d}}(\mathrm{h})$ \\
\hline Untreated PCL & $1.1 \pm 2.8$ & - & - \\
$\mathrm{UV} / \mathrm{O}_{3}$ PCL & $18.5 \pm 9.8$ & 0.0299 & 23.18 \\
Gelatin coated PCL & $17.6 \pm 14.1$ & 0.0257 & 27.02 \\
\hline
\end{tabular}
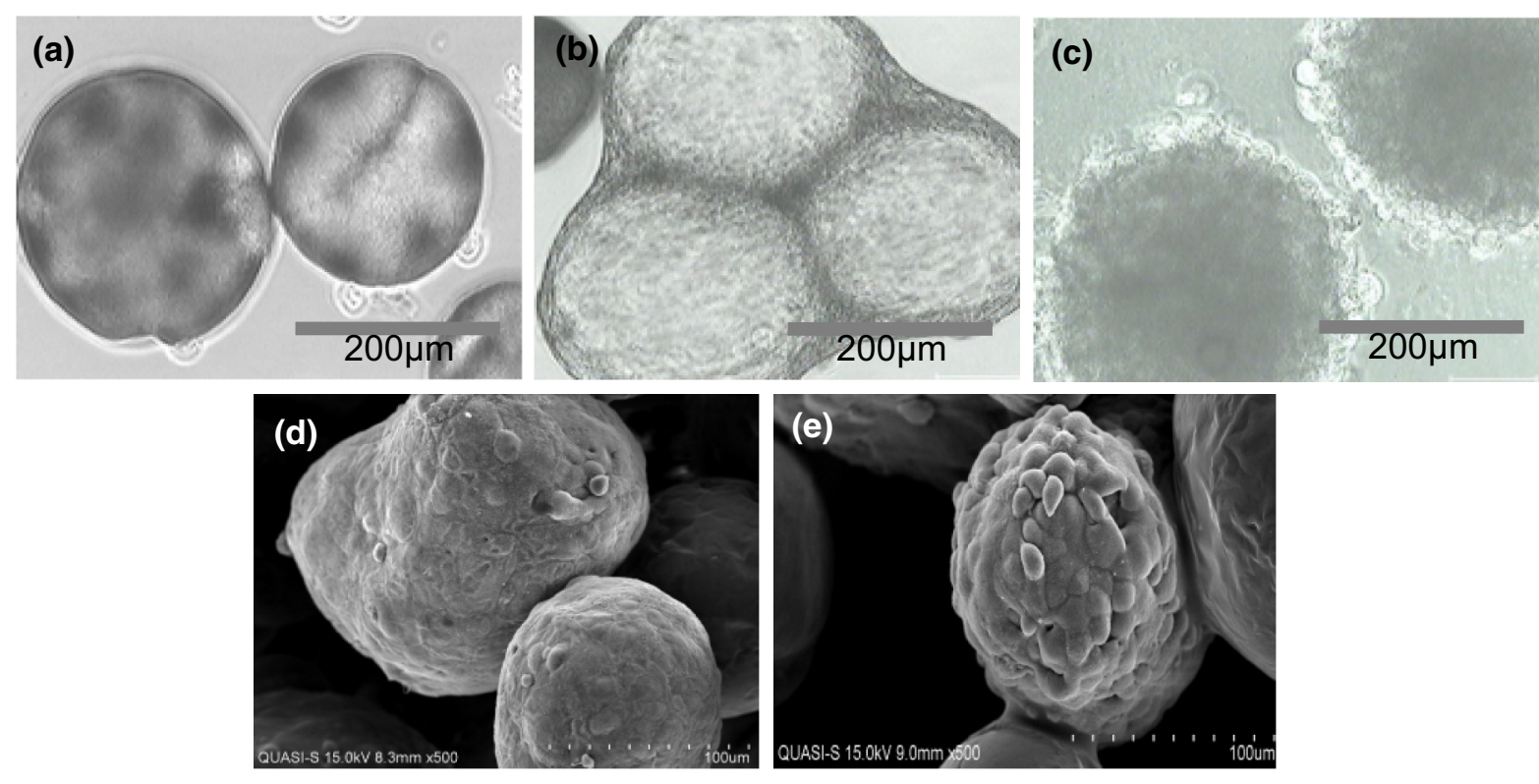

Fig. 7 Micrograph of HaCaT at $96 \mathrm{~h}$ on a untreated PCL, b UV/O 3 PCL, c Gelatin coated PCL visualized using an inverted phase contrast microscope. SEM image of $\mathbf{d} \mathrm{HaCaT}$ cells on $\mathrm{UV} / \mathrm{O}_{3} \mathrm{PCL}$ and $\mathbf{e} \mathrm{HaCaT}$ cells on gelatin-coated PCL

favorable to absorb proteins that promote cell attachment (Teare et al. 2001). An investigation conducted by Jacobson and Ryan (1982) discovered that due to the negative charges on the oxygen containing functional group surface, the amount of serum protein absorbed was about two or three times of that the positively charged surface and protein-coated surface. Experiments on oxidizing the culture dish using UV/ $\mathrm{O}_{3}$ treatment conducted by Teare et al. (2001), show that fibronectin from serum preferentially absorbed on the surface. The combination effects of electrostatic interaction as well as favorable attachment site by serum protein enhance the $\mathrm{HaCaT}$ cell attachment rate onto the $\mathrm{UV} / \mathrm{O}_{3}$ treated microcarrier, therefore, improved the cell concentration.

According to Zhou et al. (2013), each and every cell will have different attachment ligands and adherence forces to adhere to a surface. In the case of gelatin coating, it was reported that serum proteins were also absorbed on the surface but the amount was comparatively low as compared to negatively charged microcarrier (Jacobson and Ryan 1982). Gelatin may inherently contain specific biologically active cell attachment proteins which are favorable for $\mathrm{HaCaT}$ cell attachment and growth. In this present study, gelatin coated PCL may not show superior performance as compared to $\mathrm{UV} / \mathrm{O}_{3}$ PCL for $\mathrm{HaCaT}$ cells but other types of cells, particularly stem cells may show specificity for attachment towards particular form of protein (gelatin).

Figure 7 shows the morphology of HaCaT cells on untreated PCL, UV/O 3 PCL and gelatin coated PCL observed at $96 \mathrm{~h}$ of cultivation using inverted light microscope and SEM. At this time point the cells were in confluent state. Cells appeared to be flattened and spread over the surface of the microcarriers with comparatively large aggregates formed for $\mathrm{UV} / \mathrm{O}_{3}$ PCL microcarrier. 


\section{Conclusion}

Based on the statistical optimization, the optimum conditions for maximizing the carboxyl group concentration $(1495.92 \mathrm{nmol} / \mathrm{g})$ on the surface of PCL were as follows: ozone concentration of $60,110.52 \mathrm{ppm}$, sample amount of $5.5 \mathrm{~g}$, and exposure time of $60 \mathrm{~min}$. The effect of exposure time and sample amount was found to be significant as an interaction effect. Higher gelatin immobilization was achieved on $\mathrm{UV} \mathrm{O}_{3}$ treated $(320 \pm 0.9 \mu \mathrm{g} / \mathrm{g})$ microcarriers as compared to the untreated $(26.83 \pm 3 \mu \mathrm{g} / \mathrm{g})$ microcarriers indicating that the introduction of oxygen functional group on the surface of microcarriers was successful. Lastly, the growth kinetics of $\mathrm{HaCaT}$ cells were compared between untreated, $\mathrm{UV} / \mathrm{O}_{3}$ treated and gelatin coated microcarrier. In the light of the selection of dermal related cells (keratinocytes) as model in this study, the aim was to demonstrate the usability of the biodegradable PCL microcarrier in tissue applications. Microcarriers offer the advantage of mass production of cells, large scale production of bioproduct, as well as more specific application such as transplantation tools to carry cells in wound healing therapies. Keratinocytes have been reported to have great potential for treating skin diseases such as genetic abnormalities, infections and skin cancer (Deyrieux and Wilson 2007). To this end, oxidization of PCL microcarrier surface by $\mathrm{UV} / \mathrm{O}_{3}$ enhanced surface wettability and promote higher gelatin immobilization and improved cell adhesion and proliferation.

Acknowledgements The authors are grateful to the Ministry of Higher Education Malaysia, for financing the research project (PRGS 11-001-0001) under the Prototype Development Research Grant Scheme (PRGS) and to the Department of Biotechnology Engineering, International Islamic University Malaysia for their support.

\section{References}

Anderson MJ, Whitcomb PJ (2015) DOE simplified: practical tools for effective experimentation. CRC Press, Florida

Bock A, Sann H, Schulze-Horsel J, Genzel Y, Reichl U, Möhler L (2009) Growth behavior of number distributed adherent MDCK cells for optimization in microcarrier cultures. Biotechnol Progr 25:1717-1731. doi:10.1002/btpr.262

Callen BW, Lowenberg BF, Lugowski S, Sodhi RN, Davies JE (1995) Nitric acid passivation of Ti6Al4V reduces thickness of surface oxide layer and increases trace element release. J Biomed Mater Res 29:279-290
Chen DR, Bei JZ, Wang SG (2000) Polycaprolactone microparticles and their biodegradation. Polym Degrad Stab 67:455-459

Clark JT, Ruiz JD, Fan H, Brinker CJ, Swanson BI, Parikh AN (2000) A new application of UV-ozone treatment in the preparation of substrate- supported mesoporous thin films. Chem Mater 12:3879-3884

Darain F, Chan WY, Chian KS (2010) Performance of surfacemodified polycaprolactone on growth factor binding, release, and proliferation of smooth muscle cells. Soft Mater 9:64-78. doi:10.1080/1539445X.2010.520797

Davidson MR, Mitchell SA, Bradley RH (2004) UV-ozone modification of plasma-polymerised acetonitrile films for enhanced cell attachment. Colloids Surf B 34:213-219

Deyrieux AF, Wilson VG (2007) In vitro culture conditions to study keratinocyte differentiation using the HaCaT cell line. Cytotechnology 54:77-83. doi:10.1007/s10616-0079076-1

Goh TK-P, Zhang Z-Y, Chen AK-L, Reuveny S, Choolani M, Chan JKY, Oh SK-W (2013) Microcarrier culture for efficient expansion and osteogenic differentiation of human fetal mesenchymal stem cells. BioRes Open Access 2:84-97. doi:10.1089/biores.2013.0001

Gomathi N, Neogi S (2009) Surface modification of polypropylene using argon plasma: statistical optimization of the process variables. Appl Surf Sci 255:7590-7600. doi:10.1016/j.apsusc.2009.04.034

Hinkelmann K, Kempthorne O (2008) Design of experiment: introduction to experimental design, vol 2. Wiley, New York

Hong Y, Gao C, Xie Y, Gong Y, Shen J (2005) Collagen-coated polylactide microspheres as chondrocyte microcarriers. Biomaterials 26:6305-6313. doi:10.1016/j.biomaterials. 2005.03.038

Jacobson BS, Ryan US (1982) Growth of endothelial and HeLa cells on a new multipurpose microcarrier that is positive, negative or collagen coated. Tissue Cell 14:69-83. doi:10. 1016/0040-8166(82)90008-8

Kemala T, Budianto E, Soegiyono B (2012) Preparation and characterization of microspheres based on blend of poly(lactic acid) and poly( $\varepsilon$-caprolactone) with poly(vinyl alcohol) as emulsifier. Arab J Chem 5:103-108. doi:10. 1016/j.arabjc.2010.08.003

Khan W, Kapoor M, Kumar N (2007) Covalent attachment of proteins to functionalized polypyrrole-coated metallic surfaces for improved biocompatibility. Acta Biomater 3:541-549

Kim W-J, Kim S, Lee BS, Kim A, Ah CS, Huh C, Yun WS (2009) Enhanced protein immobilization efficiency on a $\mathrm{TiO}_{2}$ surface modified with a hydroxyl functional group. Langmuir 25:11692-11697. doi:10.1021/la901615e

Kwon Y, Coleman MA, Camarero JA (2006) Selective immobilization of proteins onto solid supports through split-intein mediated protein trans-splicing. Angew Chem Int Ed 45:1726-1729

Ma Z, Gao C, Ji J, Shen J (2002) Protein Immobilization on the surface of poly-L-lactic acid films for improvement of cellular interactions. Eur Polym J 38:2279-2284

Macmanus LF, Walzak MJ, Mcintyre NS (1999) Study of ultraviolet light and ozone surface modification of polypropylene. J Polym Sci, Part A Polym Chem 
37(14):2489-2501. doi:10.1002/(SICI)1099-0518(19990 715)37:14<2489:AID-POLA23>3.0.CO;2-G

Maia JL, Santana MHA (2004) The effect of some processing conditions on the characteristics of biodegradable microspheres obtained by an emulsion solvent evaporation process. Braz J 21:1-12

Mano JF, Silva GA, Azevedo HS, Malafaya PB, Sousa RA, Silva SS et al (2007) Natural origin biodegradable systems in tissue engineering and regenerative medicine: present status and some moving trends. J R Soc Interfac R Soc 4:999-1030. doi:10.1098/rsif.2007.0220

Mitchell S, Poulsson HC, Davidson MR, Emmison N, Shard G, Bradley RH (2004) Cellular attachment and spatial control of cells using micro-patterned ultra-violet/ozone treatment in serum enriched media. Biomaterials 25:4079-4086. doi:10.1016/j.biomaterials.2003.11.010

Murakami TN, Fukushima Y, Hirano Y (2003) Surface modification of polystyrene and poly (methyl methacrylate) by acti $\mathrm{v}$ e oxygen treatment. Colloid Surf B Biointerf 29:171-179

Murakami TN, Fukushima Y, Hirano Y, Tokuoka Y, Takahashi M, Kawashima N (2005) Modification of PS films by combined treatment of ozone aeration and UV irradiation in aqueous ammonia solution for the introduction of amine and amide groups on their surface. Appl Surf Sci 249:425-432. doi:10.1016/j.apsusc.2004.12.017

Prockop DJ, Udenfriend S (1960) A specific method for the analysis of hydroxyproline in tissues and urine. Anal Biochem 1:228-239

Ratner DR, Bryant JB (2004) Biomaterial: where we have been and where we are going. Annu Rev Biomed Eng 6:41-75

Sabino MA (2007) Oxidation of polycaprolactone to induce compatibility with other degradable polyesters. Polym Degrad Stab 92:986-996. doi:10.1016/j.polymdegradstab. 2007.03.010

Seland H, Gustafson C-J, Johnson H, Junker JPE, Kratz G (2011) Transplantation of acellular dermis and keratinocytes cultured on porous biodegradable microcarriers into full-thickness skin injuries on athymic rats. Burns J Int Soc Burn Inj 37:99-108. doi:10.1016/j.burns.2010.03.014

Shen H, Hu X, Yang F, Bei J, Wang S (2007) Combining oxygen plasma treatment with anchorage of cationized gelatin for enhancing cell affinity of poly(lactide-co-glycolide). Biomaterials 28:4219-4230
Steynberg T, Visagie M, Mqoco T, Idicula A, Moolman S, Richter W, Joubert A (2012) Qualitative assessment of smooth muscle cells propagated on 2D-and 3D- polycaprolactone polymers via scanning electron microscope. Biomed Res 23:191-198

Teare DOH, Emmison N, Bradley RH (2000) Cellular attachment to ultraviolet ozone modified polystyrene surfaces. Langmuir 16:2818-2824. doi:10.1021/la9907533

Teare DOH, Emmison N, Ton-That C, Bradley RH (2001) Effects of serum on the kinetics of $\mathrm{CHO}$ attachment to ultraviolet-ozone modified polystyrene surfaces. J Colloid Interface Sci 234:84-89. doi:10.1006/jcis.2000.7282

van der Velden-de Groot C (1995) Microcarrier technology, present status and perspective. Cytotechnology 18:51-56. doi:10.1007/BF00744319

Wu C (2002) Performance of an acrylic acid grafted polycaprolactone/starch composite: characterization and mechanical properties. J Appl Polym Sci 88:2888-2895

Yanagisawa K, Murakami TN, Tokuoka Y, Ochiai A, Takahashi M, Kawashima N (2006) Immobilization and enzymatic activity of glucose oxidase on polystyrene surface modified with ozone aeration and UV irradiation in distilled water and/or aqueous ammonia solution. Colloids Surf B Biointerf 48:67-71. doi:10.1016/j.colsurfb.2006.01.008

Yang Y, Porte M, Marmey P, El Hai AJ, Amedee J, Baquey C (2003) Covalent bonding of collagen on poly(L-lactic acid) by gamma irradiation. Nucl Instrum Methods 207:165-174

Yuan S, Xiong G, Roguin A, Choong C (2012) Immobilization of gelatin onto poly(glycidyl methacrylate)-grafted polycaprolactone substrates for improved cell-material interactions. Biointerphases 7:30. doi:10.1007/s13758-0120030-1

Yusilawati AN, Maizirwan M, Hamzah MS, Ng KH, Wong CS (2010) Surface modification of polystyrene beads by ultraviolet/ozone treatment and its effect on gelatin coating. Am J Appl Sci 7:724-731

Zhou W, Ma G, Su Z (2013) Microspheres for cell culture. In: Ma G, Su Z (eds) Microcapsules in biotechnology. Taylor and Francis, New York

Zhu Y, Gao C, Liu X, Shen J (2002) Surface modification of polycaprolactone membrane via aminolysis and biomacromolecule immobilization for promoting cytocompatibility of human endothelial cells. Biomacromolecules 3:1312-1319 